\title{
Profil glomerulonefritis akut pasca streptokokus pada anak yang dirawat di Bagian Ilmu Kesehatan Anak RSUP Prof. Dr. R. D. Kandou Manado
}

\author{
${ }^{1}$ Agung R. E. Hidayani \\ ${ }^{2}$ Adrian Umboh \\ ${ }^{2}$ Stefanus Gunawan \\ ${ }^{1}$ Kandidat Skripsi Fakultas Kedokteran Universitas Sam Ratulangi Manado \\ ${ }^{2}$ Bagian Ilmu Kesehatan Anak Fakultas Kedokteran \\ Universitas Sam Ratulangi Manado \\ Email: agunghidayani@gmail.com
}

\begin{abstract}
Acute post streptococcal glomerulonephritis (APSGN) is a form of inflammation of the glomerulus in histopathology showed inflammatory \& proliferation of glomeruli are preceded of infection Streptococcus group A $\beta$-hemolytic, often found in the age group of 23 years, and is twice as common in boys compared with the girls. This study aims to know the profile of APSGN in children treated at Department of Pediatrics Prof. Dr. R. D. Kandou Manado period August 2012 - August 2016. This study is a descriptive retrospective and conducted in September-November 2016. The sample of this study is all children patients being treated in the diagnosis of APSGN. The research results obtained 53 patients with diagnosis of APSGN, with ages 3-13 years, male 56.6\% and $43.4 \%$ women. Hematuria microscopic 90,6\%, edema $83 \%$, proteinuria $79,2 \%$, hypertension $60,8 \%$, Oliguria $5,7 \%$, increase of ASTO 45,3\%, decreased C3 $66 \%$, Azotemia 73,6\%, declining GFR 90,6\%, and complications AKI 17,6\%. Conclusion: APSGN was found in children aged 3-13 years are more commonly found in men than women and the clinical symptoms of the most widely found is hematuria. The importance of knowledge about APSGN for the parents and surveillance against the child in order to not easily infected is live with clean and healthy.
\end{abstract}

Keywords: glomerulonephritis, APSGN, Children

\begin{abstract}
Abstrak: Glomerulonefritis akut pasca streptokokus (GNAPS) adalah suatu bentuk peradangan glomerulus yang secara histopatologi menunjukkan proliferasi \& inflamasi glomeruli yang didahului oleh infeksi group A $\beta$-hemolitik streptokokus,sering ditemukan pada kelompok usia 2-15 tahun, dan dua kali lebih sering terjadi pada anak laki-laki dibandingkan dengan anak perempuan. Penelitian ini bertujuan untuk mengetahui profil GNAPSpada anak yang dirawat di bagian Ilmu Kesehatan Anak RSUP Prof. Dr. R. D. Kandou Manado periode Agustus 2012 - Agustus 2016. Penelitian ini merupakan penelitian deskriptif restropektif yang dilakukan pada bulan September- November 2016. Sampel penelitian adalah semua pasien anak yang dirawat di diagnosis GNAPS. Hasil penelitian didapatkan 53 pasien dengan diagnosis GNAPS, dengan usia 3-13 tahun, laki-laki 56,6\% dan perempuan $43,4 \%$. Hematuria $90,6 \%$, edema $83 \%$, proteinuria $79,2 \%$, hipertensi $60,8 \%$, Oliguria 5,7\%, peningkatan ASTO 45,3\%, penurunan C3 $66 \%$, Azetomia 73,6\%, LFG menurun 90,6\%, dan komplikasi AKI 17,6\%. Simpulan: GNAPS ditemukan pada anak usia 3-13 tahun yang lebih sering ditemukan pada laki-laki dibandingkan perempuan dan gejala klinis yang paling banyak ditemukan adalah hematuria. Pentingnya pengetahuan tentang GNAPS pada orang tua dan pengawasan terhadap anak agar tidak mudah terinfeksi dengan hidup bersih dan sehat.
\end{abstract}

Kata kunci: Glomerulonefritis, GNAPS, Anak 
Glomerulonefritis akut adalah suatu reaksi imunologis pada ginjal terhadap bakteri atau virus tertentu yang dikarakterisasi oleh cedera glomerular dengan onset mendadak. Glomerulonefritis akut yang paling sering terjadi pada anak di negara berkembang adalah setelah infeksi bakteri streptokokus beta hemolitikus grup A, yaitu glomerulonefritis akut pasca infeksi streptokokus (GNAPS). ${ }^{1,2}$

Penyakit ini ditandai dengan hematuria yang timbul mendadak, hipertensi, edem, dan penurunan fungsi ginjal. Gejala pertama yang paling sering ditemukan adalah edem palpebra. ${ }^{3}$ Glomerulonefritis akut pasca streptokokus dapat terjadi pada semua kelompok usia namun lebih sering ditemukan pada kelompok usia 2-15 tahun, sangat jarang terjadi pada anak dengan usia di bawah dua tahun dan dua kali lebih sering terjadi pada anak laki-laki dibandingkan dengan anak perempuan. ${ }^{4}$

WHO mempekirakan 472.000 kasus GNAPS terjadi setiap tahunnya secara global dengan 5.000 kematian setiap tahunnya. ${ }^{5}$ Penelitian yang dilakukan di Sri Manakula Vinayagar Medical College and Hospital India pada periode waktu Januari 2012-Desember 2014 ditemukan 52 anak dengan diagnosis GNAPS. Dari 52 pasien ditemukan 46 anak $(88,4 \%)$ dengan GNAPS, usia pasien berkisar antara 2,613 tahun, 27 anak (52\%) pada kelompok usia 5-10 tahun. ${ }^{6}$

Di Indonesia pengamatan mengenai GNA pada anakdi sebelas universitas di Indonesia pada tahun 1997-2002, lebih dari $80 \%$ dari 509 anak dengan GNA mengalami efusi pleura, kardiomegali serta efusi perikardial, dan 9,2\% mengalami ensefalopati hipertensif. Selama 5 tahum sejak 1998-2002, didapatkan 45 pasien GNA $(0,4 \%)$ yaitu diantara 10.709 pasien yang berobat di Departemen Ilmu Kesehatan Anak RSCM. Empat puluh lima pasien ini terdiri dari 26 laki-laki dan 19 perempuan yang berumur antara 4-14 tahun, dan yang paling sering adalah 6-11 tahun. ${ }^{3}$

Angka kejadian ini relatif rendah, tetapi menyebabkan morbiditas yang bermakna. Dari seluruh kasus, 95\% diperkirakan akan sembuh sempurna, 2\% meninggal selama fase akut dari penyakit, dan $2 \%$ menjadi glomerulonefritis kronis. ${ }^{7}$

Berdasarkan latar belakang tersebut dan berbagai variasi hasil penelitian yang telah dilakukan menarik perhatian peneliti untuk melakukan penelitian tentang profil glomerulonefritis akut pasca streptokokus pada anak yang dirawat di RSUP Prof. dr. R.D Kandou Manado Periode Agustus 2012- Agustus 2016.

\section{METODE PENELITIAN}

Penelitian ini merupakan penelitian deskriptif restropektif dengan menggunakan rekam medik pasien untuk mengetahui profil pasien GNAPS pada anak periode Agustus 2012-Agustus 2016. Sampel penelitian ini ialah semua pasien anak yang didiagnosis GNAPS di bagian Ilmu Kesehatan Anak RSUP Prof. Dr. R. D. Kandou Manado dengan kriteria eksklusi yaitu pasien dengan data rekam medik tidak lengkap. Analisis data menggunakan analisis univariat dengan menggunakan SPSS 22.0.

\section{HASIL PENELITIAN}

Berdasarkan data yang diperoleh dari rekam medik pada pasien GNAPS yang di rawat di Bagian Ilmu Kesehatan Anak Prof. Dr. R. D. Kandou periode waktu Agustus 2012-Agustus 2016 sebanyak 53 anak.

Tabel 1. Distribusi berdasarkan tahun

\begin{tabular}{ccc}
\hline Tahun & Jumlah & \% \\
\hline 2012 & 8 & 15,1 \\
2013 & 10 & 18,9 \\
2014 & 19 & 35,8 \\
2015 & 7 & 13,2 \\
2016 & 9 & 17,0 \\
Total & 53 & 100,0 \\
\hline
\end{tabular}

Tabel 2. Distribusi berdasarkan usia

\begin{tabular}{ccc}
\hline Usia (tahun) & Jumlah & \% \\
\hline $3-6$ & 14 & 26,4 \\
$7-9$ & 25 & 47,2 \\
$10-13$ & 14 & 26,4 \\
Total & 53 & 100,0 \\
\hline
\end{tabular}


Tabel 3. Distribusi berdasarkan jenis kelamin

\begin{tabular}{ccc}
\hline Jenis kelamin & Jumlah & \% \\
\hline L & 30 & 56,6 \\
P & 23 & 43,4 \\
Total & 53 & 100,0 \\
\hline
\end{tabular}

Tabel 4. Distribusi berdasarkan gejala klinis

\begin{tabular}{lll}
\hline Gambaran klinis & Jumlah & $\%$ \\
\hline Edema & & \\
-Tanpa Edema & 9 & 17,0 \\
-Lokal & 40 & 56,6 \\
-Anasarka & 14 & 26,4 \\
Hipertensi & & \\
-Normal & 16 & 30,2 \\
-Stage I & 20 & 37,7 \\
-Stage II & 17 & 32,1 \\
Oliguria & & \\
-tanpa oliguria & 50 & 94,3 \\
-oliguria & 3 & 5,7 \\
Demam & & \\
-Tanpa demam & 29 & 54,7 \\
-Demam & 24 & 45,3 \\
\hline
\end{tabular}

Tabel 5. Distribusi berdasarkan laboratorium urin

\begin{tabular}{lcc}
\hline Pemeriksaan urin & Jumlah & \% \\
\hline Proteinuria & & \\
-Negatif & 11 & 20,8 \\
-+1 & 6 & 11,3 \\
-+2 & 12 & 22,6 \\
-+3 & 13 & 24,5 \\
- +4 & 11 & 20,8 \\
Hematuria & & \\
mikroskopik & & \\
-Tanpa hematuria & 5 & 9,4 \\
-Hematuria & 48 & 90,6 \\
& & \\
Eritrosit & & \\
-Negatif & 5 & 9,4 \\
-Positif & 48 & 90,6 \\
Leukosit & & \\
-Negatif & 15 & 23,3 \\
-Positif & 38 & 71,7 \\
Silinder granula & & \\
-Negatif & 49 & 92,5 \\
-Positif & 4 & 7,7 \\
Silinder hialin & & \\
-Negatif & 42 & 79,2 \\
-Positif & 11 & 20,8 \\
\hline
\end{tabular}

Tabel 6. Distribusi berdasarkan laboratorium darah

\begin{tabular}{lcc}
\hline Pemeriksaan darah & Jumlah & \% \\
& & \\
\hline ASTO & 24 & 45,3 \\
$-\leq 200$ & 29 & 54,7 \\
$-\geq 200$ & & \\
C3 & 18 & 34,0 \\
$-\geq 50$ & 35 & 66,0 \\
$-\leq 50$ & & \\
LED & 18 & 34,0 \\
$-\geq 10$ & 35 & 66,0 \\
$-\leq 10$ & & \\
HB & 44 & 83,0 \\
- $\geq 10$ & 9 & 17,0 \\
- $\leq 10$ & & \\
Azotemia & 39 & 73,6 \\
-Azotemia & 14 & 26,4 \\
-Normal & & \\
LFG & 5 & 9,4 \\
-Meningkat & 29 & 54,7 \\
-Menurun $\geq 25 \%$ & 13 & 24,5 \\
-Menurun $\geq 50 \%$ & 6 & 11,3 \\
-Menurun $\geq 75 \%$ & & \\
Trombosit & 34 & 64,2 \\
-Normal & 19 & 35,8 \\
-trombositosis & & \\
Leukosit & 31 & 58,5 \\
-Normal & 22 & 41,5 \\
-Leukositosis & & \\
\hline & &
\end{tabular}

Tabel 7. Distribusi berdasarkan komplikasi

\begin{tabular}{lcc}
\hline Komplikasi & Jumlah & $\mathbf{\%}$ \\
\hline -Tanpa komplikasi & 42 & 82,4 \\
- AKI & 9 & 17,6 \\
\hline
\end{tabular}

\section{BAHASAN}

Berdasarkan data yang diperoleh dari rekam medik pasien GNAPS yang dirawat di Bagian Ilmu Kesehatan Anak Prof. Dr. R. D. Kandou periode waktu Agustus 2012-Agustus 2016 didapatkan 53 orang. Angka kejadian tertinggi GNAPS terjadi pada tahun 2014 yaitu 19 kasus $(35,8 \%)$ dan angka kejadian terendah terjadi pada tahun 2015 yaitu 7 kasus GNAPS (13,2\%). Berdasarkan jenis kelamin GNAPS lebih banyak terjadi pada laki-laki $(56,6 \%)$ daripada perempuan $(43,4 \%)$ dengan rasio perbandingan 1,7:1. Anak yang menderita GNAPS pada kelompok usia 3-13 tahun dengan insiden tertinggi pada usia 7-9 tahun. Hal ini sesuai dengan penelitian yang dilakukan di Rumah Sakit Wahidin 
Sudirohusodo Makassar pada tahun 2005 bahwa GNAPS lebih sering ditemukan pada laki-laki dibandingkan perempuan. Pada penelitian yang dilakukan di Sri Manakula Vinayagar Medical College and Hospital India 2015 ditemukan bahwa usia pasien GNAPS berkisar antara 2,6-13 tahun. ${ }^{6}$

Pada penelitian berdasarkan gejala klinis edema merupakan gejala klinis terbanyak $(83 \%)$ yang dialami oleh pasien; $14 \%$ dengan edema anasarka dan $30 \%$ edema lokal yaitu edema palpebra. Hipertensi terjadi pada $59,8 \%$ pasien; $37,7 \%$ pada hipertensi stage I dan $32,1 \%$ pada hipertensi stage II. Pada penelitian sebelumnya yang dilakukan oleh Mossie dan Shimelis ${ }^{8}$ didapatkan juga hasil bahwa $88,2 \%$ pasien GNAPS mengalami edema dan $85,3 \%$ pasien mengalami hipertensi.

Kepustakaan menyebutkan bahwa edema merupakan gejala klinis yang paling sering, umumnya pertama kali timbul dan hipertensi merupakan gejala yang terdapat pada $60-70 \%$ kasus GNAPS. Edema terjadi akibat terjadinya retensi $\mathrm{Na}$ dan air, sehingga dapat menyebabkan edema dan hipertensi. ${ }^{9}$

Gejala klinis oliguria dialami oleh 3 orang pasien $(5,7 \%)$; hal ini selaras dengan teori yang menyatakan bahwa oliguria jarang dijumpai. ${ }^{9}$ Pada penelitian di Sri Manakula Vinayagar Medical College and Hospital India 2015 ditemukan gejala klinis lainnya yaitu demam sebanyak $28,5 \%$ sedangkan pada penelitian ini ditemukan angka yang lebih tinggi yaitu demam dialami oleh $50,9 \%$ pasien. ${ }^{6}$

Berdasarkan hasil penelitian pada pemeriksaan laboratorium urin ditemukan proteinuria pada $79,8 \%$ pasien GNAPS dan 90,6\% dengan hematuria. Pada pemeriksaan sedimen urin ditemukan 90,6\% dengan hasil eritrosit positif, $71,7 \%$ dengan leukosit positif, silinder granula ditemukan pada $7,5 \%$ pasien dan silinder hialin ditemukan pada 20,8\% pasien. Hal ini sejalan dengan penelitian yang dilakukan Albar ${ }^{4}$ yang mendapatkan bahwa $84-100 \%$ pasien mengalami hematuria mikroskopik dan pada penelitian Mossie dan Shimelis $^{8}$ didapatkan $86,8 \%$ pasien GNAPS dengan proteinuria.

Hasil laboratorium urin pada penelitian ini selaras dengan teori yang mengatakan bahwa hematuria mikroskopik umumnya ditemukan pada semua pasien GNAPS dan akan didapatkan eritrosit, leukosit, proteinuria, silinder granula dan silinder hialin pada pasien yang didiagnosis dengan GNAPS. ${ }^{9}$

Pada hasil pemeriksaan laboratorium darah pada 53 pasien ditemukan $54,7 \%$ pasien mengalami peningkatan titer ASTO, $66 \%$ pasien dengan penurunan serum $\mathrm{C} 3$, $34 \%$ pasien dengan peningkatan LED, $17 \%$ pasien dengan penurunan hemoglobin, $73,6 \%$ pasien dengan azotemia (6 orang hanya dengan peningkatan kadar ureum dan 8 orang hanya dengan peningkatan kreatinin), 92,5\% pasien dengan penurunan LFG, 35,8\% pasien mengalami trombositosis, dan $41,5 \%$ pasien mengalami leukositosis. Hal ini sejalan dengan penelitian yang dilakukan oleh Kumar et al. ${ }^{10}$ yang melaporkan penurunan $\mathrm{Hb}$ tidak ditemukan pada semua pasien GNAPS pada saat adanya peningkatan kadar ureum dan kreatinin (azetonemia) dan kepustakaan menyebutkan LED akan meninggi pada fase akut dan menurun setelah gejala klinik menghilang. LED meningkat dan kadar $\mathrm{Hb}$ menurun sebagai akibat hipervolemia. Umumnya LFG berkurang disertai penurunan kapasitas ekskresi air dan garam yang menyebabkan ekspansi volume cairan ekstrasel. ${ }^{10}$

Pada penelitian yang dilakukan di RSUP Prof. Dr. R. D. Kandou tidak semua pasien GNAPS mengalami peningkatan titer ASTO dan penurunan komplemen C3. Hal ini tidak selaras dengan penelitian yang dilakukan Kumar et al. ${ }^{10}$ yang menyatakan bahwa seluruh pasien GNAPS akan mengalami peningkatan titer ASTO dan penurunan $\mathrm{C} 3$.

Komplikasi yang dialami oleh pasien GNAPS pada penelitian ini ialah gangguan ginjal akut yang dialami oleh 17,6\% pasien. Pada penelitian yang dilakukan di Nationwide Children's Hospital, USA tahun 2016 ditemukan angka kejadian lebih 
tinggi yaitu gagal ginjal akut ditemukan pada $53 \%$ pasien GNAPS. ${ }^{11}$ Acute kidney injury merupakan ketidakmampuan ginjal dalam mengatur keseimbangan cairan dan elektrolit yang ditandai dengan LFG yang menurun; keadaan tersebut ditandai dengan peningkatan kadar ureum dan kreatinin darah, dan sebagian kasus menunjukan penurunaan produksi urin. ${ }^{12}$

\section{SIMPULAN}

Berdasarkan hasil penelitian pada anak yang di rawat di Bagian Ilmu Kesehatan Anak RSUP Prof. R. D Kandou Manado dapat disimpulkan bahwa: prevalensi tertinggi GNAPS terjadi pada tahun 2014 dengan jenis kelamin laki-laki lebih banyak dari pada wanita $(1,7: 1)$ dengan insiden tertinggi pada usia 7-9 tahun dengan gejala klinis yang paling sering ditemukan edema, pada hasil pemeriksaan laboratorium tidak ditemukan peningkatan ASTO dan penurunan C3 pada semua pasien dan komplikasi yang paling sering ditemukan adalah gangguan ginjal akut.

\section{SARAN}

Pentingnya edukasi GNAPS terhadap orang tua agar dapat mengetahui gejala gejala penyakit GNAPS dan pengawasan orang tua pada anak yang telah di diagnosis GNAPS serta perlunya penerapan perilaku hidup bersih dan sehat seperti mencuci tangan,menggunakan masker dan merawat kebersihan kulit agar terhindar dari infeksi streptokokus.

\section{DAFTAR PUSTAKA}

1. Hassan R, Alatas H. Buku Kuliah Ilmu Kesehatan Anak 2. Jakarta: Bagian Ilmu Kesehatan Anak FKUI, 2007; p. 835.

2. Rachmadi D. Diagnosis dan penatalaksanaan glomerulonefritis akut. Simposium Nasional II IDAI cabang Lampung; 2010 April 24-25; Bandar Lampung.
3. Pardede OS, Trihono PP, Tambunan T. Gambaran klinis glomerulonefritis akut pada anak di departemen ilmu kesehatan anak RSCM Jakarta. Sari Pediatri. 2005;6:144-8.

4. Albar H, Rauf S. The profile of acute glomerulonephritis among Indonesian children. Paediatrica Indonesiana. 2005;45:264-9.

5. Kher KK. Acute Glomerular diseases in children. The Open Urology \& Nephrology Journal. 2015;8:104-116

6. Arunagirinathanm A, Arayanaswamy DK, Thirunavukaransu B, Raghavan A, Raghavendhran VD. Clinical spectrum and outcome of acute post-infectious glomerulonephritis in children: A Hospital Based Study. International Journal of Scientific Study. 2015;3:164.

7. Carapetis JR, Steer AC, Mullolans EK, Weber M. The global burden of group a streptococcal diseases. The Lancet Infectious Diseases. 2005;5:685-94.

8. Mossie L, Shimelis D. Outcome of children with acute post streptococcal glomerulonephritis in ticur anbesa. Ethitopian Journal of Pediatrics and Child Health.2012;8:8.

9. Rauf S, Albar H, Aras J. Konsensus glomerulonefritis akut paska streptokokus. Unit Kerja Nefrologi Ikatan Dokter Anak Indonesia, 2012.

10. Kumar GV, Kumar A, Kumar V. study of laboratory profil of acute post streptococcal glomerulonephritis the time of presentation in children. IJHRS. 2015;5:103-7.

11. Ayoob RM, Schwaderer AL. Acute kindney injury and atypical features during pediatris poststreptococcal glomerulonephritis. International Journal Nephrology. 2016;10.

12. Nilawati GAP. Kejadian acute kidney injury dengan kriteria prifle pada unit perawatan intensif anak rumah sakit Sanglah Denpasar. Sari Pediatri. 2012;14:158 